\title{
Influence of slump folds on tectonic folds: an example from the Lower Ordovician of the Anglo-Brabant Deformation Belt (Belgium)
}

\author{
R. BECKERS ${ }^{1} \&$ T. N. DEBACKER ${ }^{2}$ \\ ${ }_{4}^{1}$ Research Unit of Palaeontology, Ghent University, Krijgslaan 281/S8, 9000 Ghent, Belgium \\ $5^{2}$ Structural Geology \& Tectonics Group, Katholieke Universiteit Leuven, Redingenstraat 16, B-3000 Leuven, Belgium \\ .(e-mail: timothy.debacker@geo.kuleuven.ac.be)
}

\begin{abstract}
7 Abstract: Although it is generally accepted that buckle folds will not develop in a perfectly planar layer without the presence of some irregularity or perturbation at which the folds initiate, there are very few cases in which individual natural folds can be linked to specific irregularities. Within the Lower Ordovician Abbaye de Villers Formation, Anglo-Brabant Deformation Belt, metre-scale tectonic folds occur, of which the position and, to a certain extent, the geometry appear to be controlled by slump folds and related features. The metrescale tectonic folds, interpreted as parasitic structures on the limb of a large-scale host fold, occur only within a stratigraphic level affected by slumping. In this level, tectonic antiforms tend to form superimposed on antiformal slump folds and on zones of abrupt, slump-related thickness increase, and tectonic synforms on synformal slump folds and on zones of abrupt thickness decrease. The rather irregular 3D geometry of sedimentary sequences suggests that many more similar cases should exist in which folds can be linked to specific irregularities. However, possibly it is also this abundance of irregularities in sedimentary sequences, in combination with fold and outcrop scale, that makes it difficult to attribute a particular fold to a particular perturbation.
\end{abstract}

20 Keywords: Brabant Massif, cleavage, folds, slump structures.

21 One of the most intriguing questions in structural geology is 22 why particular structures form at particular localities. In the 23 case of folding, theories and experiments have shown that 24 buckle folds will not develop in a perfectly planar layer without 25 the presence of some irregularity or perturbation at which the 26 folds initiate (Cobbold 1975; Lewis \& Williams 1978; Williams et al. 1978; Abbassi \& Mancktelow 1990, 1992; Price \& Cosgrove 1990; Mancktelow 1999; Zhang et al. 2000; Williams \& Jiang 2001). In addition, perturbations may also influence the shape of the resulting buckle folds (e.g. Cobbold 1975; Williams et al. 1978; Abbassi \& Mancktelow 1990, 1992; Mancktelow 1999). The perturbations may be an original property of the layered system, such as a local layer thickening or the presence of isolated competent bodies (e.g. channels, intrusive bodies) or may be induced by failure during initial deformation (e.g. Cobbold 1975; Abbassi \& Mancktelow 1990; Price \& Cosgrove 1990; Zhang et al. 2000; Williams \& Jiang 2001). Also, local rheological variations or local reductions in cohesive strength may act as perturbations (Price \& Cosgrove 1990; Williams \& Jiang 2001).

The quasi-periodic form of many natural fold trains is comparable with those produced in numerical models, leading to the suggestion that irregularities in fold shape and orientation observed in natural fold trains are also determined by the location and shape of initial perturbations (Mancktelow 1999). .6 However, judging from the literature, natural examples of perturbations demonstrated to have acted as buckle fold initiation points and to have influenced the final fold shape are very rare. For instance, in the Brabant Massif, representing the Belgian part of the Early Palaeozoic Anglo-Brabant Deformation Belt, the Asquempont synform and its slightly oblique orientation with respect to the general tectonic trend may result from the presence of a large wedge-like overturned slump sheet in the synform hinge zone (Debacker et al. 2001). Similarly, in the same outcrop area, the competent Fauquez volcanoclastic deposits, which show a strong eastward decrease in thickness, may have influenced the position and geometry of the largescale Fauquez antiform, and the local, non-cylindrical parasitic folds within it (Debacker 2001). However, although both the large-scale slump sheet and the volcanoclastic deposits are likely to have acted as large-scale perturbations, it is difficult to demonstrate this supposed relationship. This is mainly due to the large scale of the tectonic folds and the poor degree of - exposure.

In this study, natural examples are given of syn-cleavage buckle folds, of which the location and to a certain extent also 13 the geometry are controlled by soft-sediment deformation fea14 tures, which acted as perturbations during tectonic layer-parallel 5 shortening. These examples are found within a specific lithostratigraphic unit, the Abbaye de Villers Formation, in the south7 ern part of the Brabant Massif, Anglo-Brabant Deformation Belt.

\section{Geological setting}

19 The Brabant Massif is a poorly exposed, low-grade meta20 morphic, Early Palaeozoic slate belt in North and Central 2 Belgium. It represents the southeastern part of the largely 22 concealed Anglo-Brabant Deformation Belt, one of the defor23 mation belts of Eastern Avalonia (Fig.1; Van Grootel et al. 24 1997; Verniers et al. 2002). The Brabant Massif has an 25 anticlinal subcrop appearance, with deposits ranging in age 26 from earliest Cambrian in the core to late Silurian along the 27 rims, and is unconformably overlain by undeformed, diagenetic 28 Givetian and younger sequences (Legrand 1968; De Vos et al. 29 1993; Van Grootel et al. 1997; Verniers et al. 2002). Through30 out the exposed parts of the massif, there is only evidence for 31 one single-phase progressive deformation (e.g. Sintubin 1997, 2 1999; Verniers et al. 2002; Debacker et al. 2004b, 2005, 


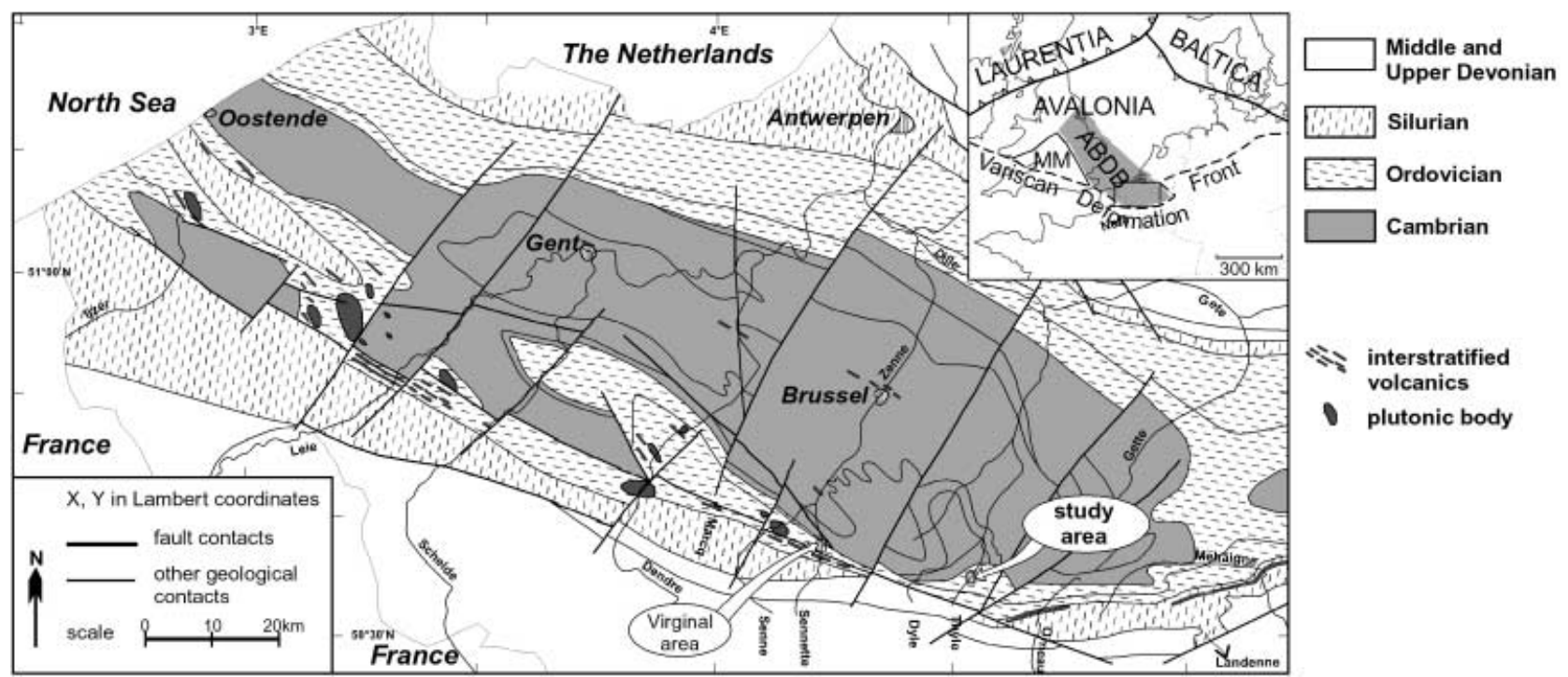

Fig. 1. Geological subcrop map of the Brabant Massif (after De Vos et al. 1993; Van Grootel et al. 1997) showing the position of the study area (see Fig. 2) and of the Virginal area (see Fig. 10). The inset shows the position of the Brabant Massif within the Anglo-Brabant Deformation Belt (ABDB) along the NE side of the Midlands Microcraton (MM) in the context of Avalonia, Baltica and Laurentia.

and references therein). This deformation phase, termed the Brabantian deformation phase, is considered to have taken place between the late Llandovery and the Emsian (Debacker et al. 2005) and is tentatively attributed to an anticlockwise rotation of the Midlands Microcraton (Verniers et al. 2002). The main features associated with this deformation are folds with a welldeveloped cogenetic cleavage. In the Ordovician-Silurian sequences in the southern part of the massif, subhorizontal to gently plunging folds occur, with a south-verging asymmetry, a common stepfold geometry, and sizes ranging from decimetreto kilometre-scale. The small- and meso-scale tectonic folds generally occur within the hinge zones of the hectometre- to kilometre-scale stepfolds (e.g. Debacker et al. 1999, 2001, 2005; Debacker 2001)

The studied folds occur within the Lower Ordovician Abbaye de Villers Formation (uppermost middle to upper Arenig) in the Thyle valley (Fig. 1). Twenty-one outcrops were studied along a $400 \mathrm{~m}$ long, north-south-directed discontinuous outcrop section (Figs 2 and 3). From a structural point of view, the section is situated within the subhorizontal to gently south-dipping northern limb of a kilometre-scale antiformal stepfold (Herbosch et al. 2002). The Abbaye de Villers Formation consists of bioturbated, grey to dark grey, fine-grained sandstone to mudstone, with an irregular, lenticular centimetre-scale lamination (Fig. 4). Characteristically, the fine-grained sandstone laminae have rather diffuse limits (Verniers et al. 2001). These sediments were deposited in a shelf environment, when Avalonia was already a separate continent, drifting away from Gondwana towards Baltica (Verniers et al. 2002). Within the Abbaye de Villers Formation two lithological units are distinguished (Fig. 3) (Beckers 2003, 2004). The northern, stratigraphically lower unit, with a minimum thickness of $10 \mathrm{~m}$ (outcrops 1-12 and 14), has a wellstratified outcrop appearance, clearly reflecting the characteristic centimetre-scale lamination. The southern, stratigraphically upper unit, with a minimum thickness of $75 \mathrm{~m}$ (outcrops 13 and 15-20), is slightly more sandy and, although also having an irregular to lenticular centimetre-scale lamination (Fig. 4), has a more massive outcrop appearance. The transition between the two units is gradual.

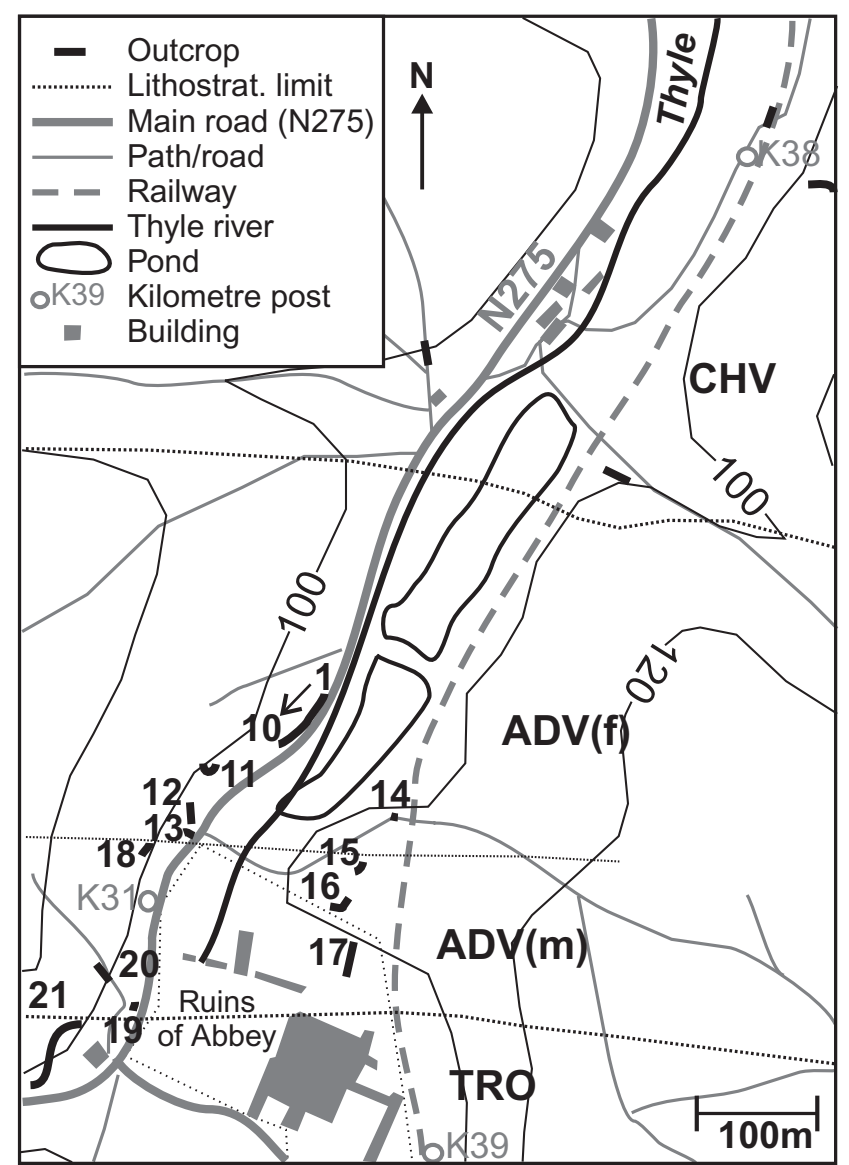

Fig. 2. Simplified topographic map of the study area around the abbey of Villers, with the position of the 21 outcrops studied. The approximate limits between the Chevlipont Formation (CHV; Tremadoc), the Abbaye de Villers Formation (ADV; Arenig; ADV(m): upper unit; ADV(f): lower unit) and the Tribotte Formation (TRO; upper Arenig) are shown, based on Herbosch \& Lemonne (2000) and personal observations. 


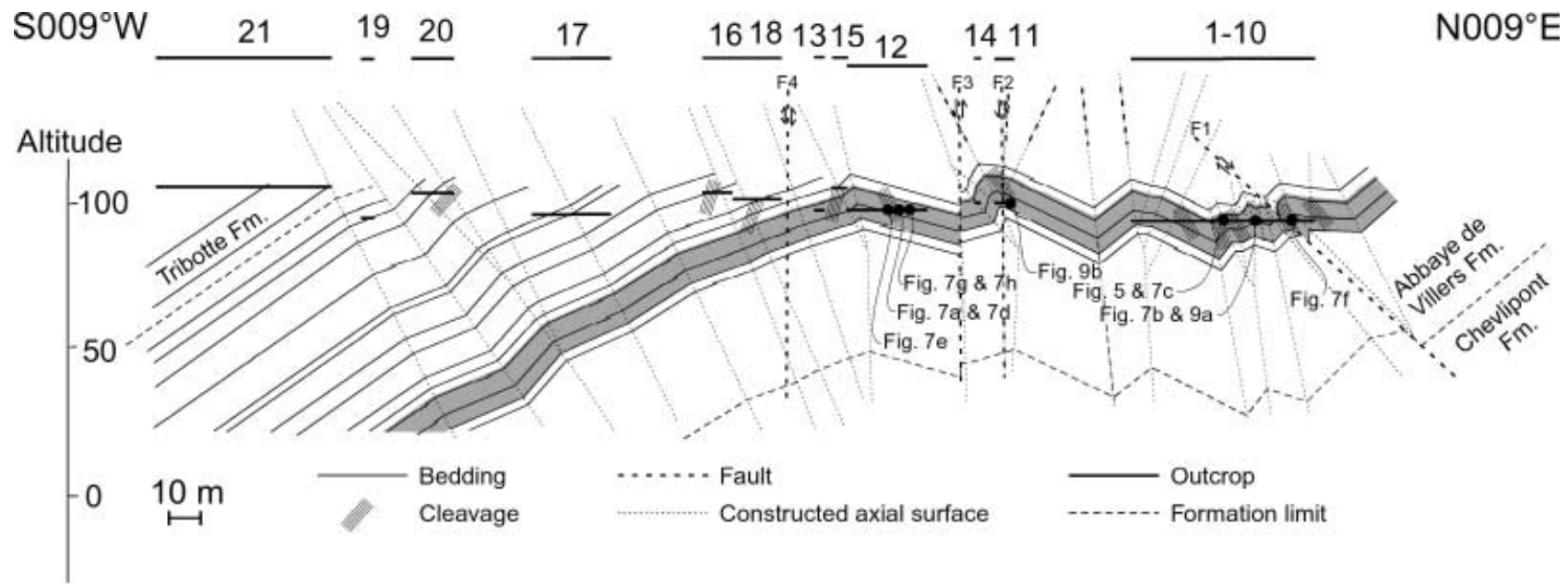

Fig. 3. Cross-section of the study area (modified after Beckers 2003, 2004), constructed by means of the kink band method, showing the position of the outcrops (1-21). The cross-section shows a hectometre-scale, gentle antiform with a hinge zone situated around the southern part of outcrop 12 and the northern part of outcrop 15. Meso-scale folds are observed only in the minimum c. 10\&thinsp;m thick lower unit of the Abbaye de Villers Formation (marked in grey). It should be noted that, because of the isolated position of the pre-cleavage folds between relatively undeformed beds, the cross-section is based entirely on the syn-cleavage folds; pre-cleavage changes in bedding orientation have not been taken into account. The poorly constrained limit between the Abbaye de Villers Formation and the underlying Chevlipont Formation (Tremadoc) is based on Herbosch \& Lemonne (2000).

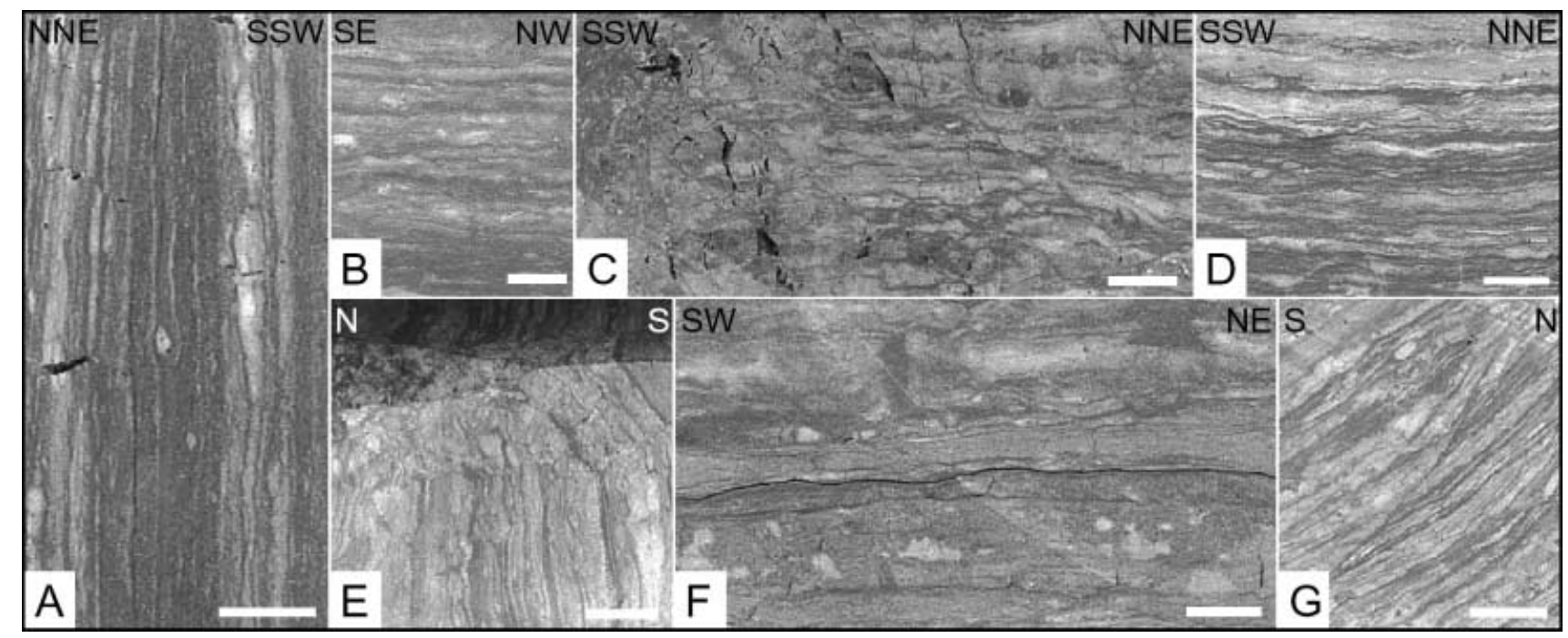

Fig. 4. The Abbaye de Villers Formation in the Thyle valley: characteristic lithologies (b, d: upper unit; a, c, e, f, g: lower unit) and examples of smallscale soft-sediment deformation (c, e, g). The scale-bar represents $1 \&$ thinsp;cm. (a) Typical laminated, bioturbated lithology; diffuse limits and lenticular nature of sandy beds should be noted (TD1252; outcrop 6; bedding: 115/80SW). (b) Typical, laminated, bioturbated lithology; diffuse limits of sandy beds should be noted (TD1260; outcrop 18; bedding: 138/30SW). (c) Irregular, slightly deformed (bioturbated?) bedding, which becomes more fragmented towards the south, and, at $1 \&$ thinsp;cm from the left border, abuts on a steep, pre-cleavage breccia, consisting of a pelitic matrix with small, isolated, sandstone and siltstone fragments (TD1255; outcrop 11; bedding: 295/22NE). (d) Typical, laminated, bioturbated lithology; diffuse limits and lenticular nature should be noted (TD1259; outcrop 15; bedding: 115/05SW). (e) Oblique view of sample, showing typical laminations that are truncated by a small NW-dipping welded fault; above the fault, bedding is tilted and brecciated (RB02-31; outcrop 12; bedding: 081/39S). (f) Silty to sandy, bioturbated level; some sandy levels have diffuse limits (up) whereas other have sharp limits (centre) (TD1257; outcrop 11; bedding: 317/26NE). (g) Bioturbated and slightly deformed laminated lithology, affected by a gently south-dipping welded detachment (upper right to lower left; RB02-29; outcrop 8; bedding: $351 / 10 \mathrm{E})$.

\section{Cleavage-fold relationships}

\section{General}

Along the outcrop section, cleavage dip shows a large-scale change. In the northern outcrops (outcrops 1-12 and 14; Fig. 3), where the sheet dip is subhorizontal, cleavage generally dips to the north, whereas in the southern outcrops (outcrops 13 and
15-21; Fig. 3), where the sheet is gently south-dipping, cleavage dips to the south. Hence, the large-scale structure is that of a hectometre-scale gentle antiform, with a well-developed divergent cleavage fan and a hinge zone situated around the northern part of outcrop 12 and the southern part of outcrop 15 (Fig. 3). Within this gentle antiform, numerous metre-scale folds occur, as mentioned previously by several workers (e.g. Anthoine \& 
Anthoine 1943; Michot 1977). Significantly, these folds occur only in the northern outcrops. On the basis of the cleavage-fold relationships these can be divided into pre-cleavage folds and syn-cleavage folds.

\section{Syn-cleavage folds}

The syn-cleavage folds show a pronounced divergent cleavage fan, symmetrical about the fold hinges, with opposing senses of cleavage refraction in the two fold limbs. The folds are of decimetre- to metre-scale and usually have open interlimb angles. Most folds have a stepfold geometry with a marked southverging asymmetry, relatively straight limbs, subangular to rounded hinges and moderately north-dipping axial surfaces (e.g. Fig. 5; see also Fig. 7c). These folds are comparable with fold types 2D and 2E of Hudleston (1973). Locally, less asymmetric folds are observed (e.g. outcrop 4), with two moderately dipping limbs and steeply north-dipping to subvertical axial surfaces. These folds, comparable with fold type 2C of Hudleston (1973), are usually better rounded than the stepfolds. In the stepfolds, cleavage usually dips to the north in both limbs, compatible with the generally north-dipping cleavage in the northern outcrops. However, because of the divergent cleavage fanning, in the moderately south-dipping limbs of the less asymmetric folds, locally south-dipping cleavage planes occur.

The fold hinge lines are subhorizontal to gently plunging, with a mean WNW-ESE trend (Fig. 6). However, a considerable variation in fold hinge-line orientation exists, showing a difference of $76^{\circ}$ between the two most extreme plunge directions $\left(076-256^{\circ}\right.$ and $\left.152-332^{\circ}\right)$. Outcrop observations show that this variation in fold hinge-line orientation occurs throughout the section. In some outcrops, neighbouring folds show markedly

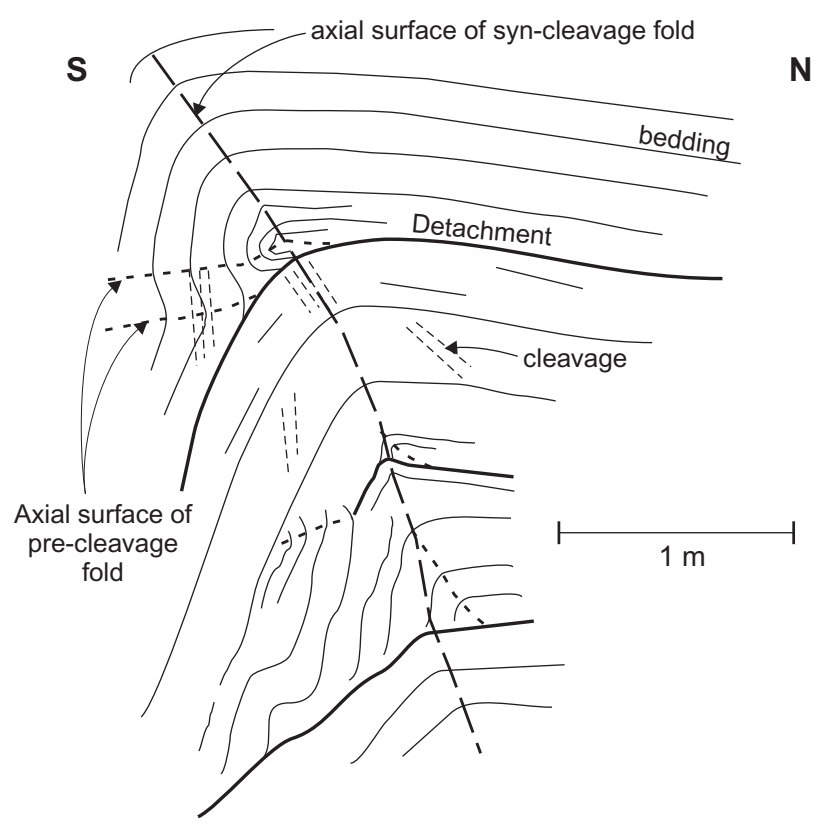

Fig. 5. Example of a syn-cleavage antiform (outcrop 6) superimposed on a pre-cleavage deformation zone. The syn-cleavage stepfold-like antiform, comparable with fold type 2D of Hudleston (1973), has a welldeveloped divergent cleavage fan, symmetrical about the fold hinge. In contrast, the small folds in its southern limb have an axial surface that is cut by the cleavage and hence have a pre-cleavage origin. The precleavage folds are related to the pre-cleavage detachments.

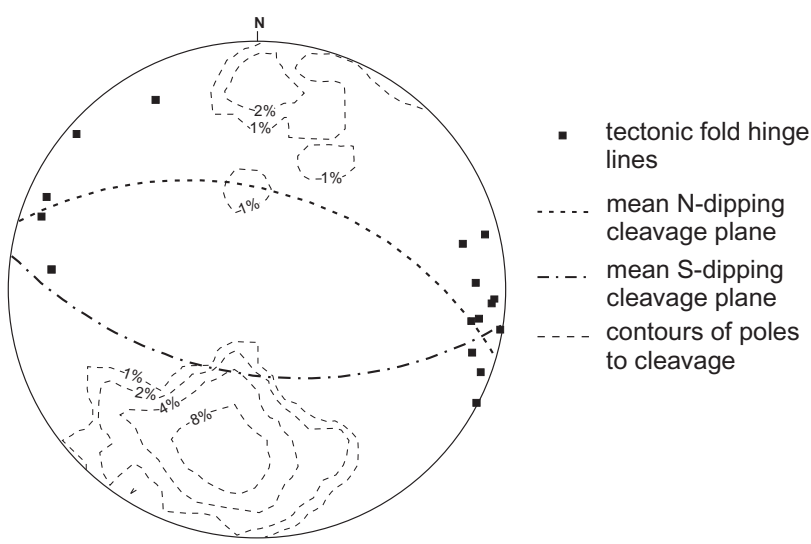

Fig. 6. Lower-hemisphere equal-area projection showing the orientation of the syn-cleavage fold hinge lines and the cleavage (mean cleavage planes and contours of poles to cleavage).

different plunge directions: a $33^{\circ}$ difference in plunge direction occurs between the southernmost antiform of outcrop 3 and the northernmost antiform of outcrop 4 , and a $25^{\circ}$ difference in plunge direction occurs between the antiform and the synform in outcrop 11. To a large extent, this variation in plunge direction is reflected by changes in cleavage transection (Fig. 6). Although in fold profile the cleavage is axial planar (e.g. Fig. 5), an axial cleavage transection (sensu Johnson 1991) is common, both clockwise (up to $20^{\circ}$ ) and anticlockwise (up to $31^{\circ}$ ). Also, the plunge of the hinge lines varies slightly, not only between adjacent folds, but also within individual folds (e.g. outcrop 11). This reflects a periclinal fold shape.

\section{Pre-cleavage folds}

The pre-cleavage nature is demonstrated by the fact that cleavage is not axial planar to the folds and does not show a symmetrical fanning about the fold hinges, but crosscuts the axial surface and shows the same sense of cleavage refraction in both fold limbs (e.g. Fig. 7b, c, f-h). Obviously, this characteristic can be used only in those cases where cleavage is oblique to the axial surface of the pre-cleavage folds. However, because of the divergent cleavage fanning within the syn-cleavage folds, a pre-cleavage fold on the limb of a syn-cleavage fold, with the same axial surface orientation as the syn-cleavage fold, can still be crosscut obliquely by the cleavage, and hence can be recognized as a precleavage feature (e.g. Fig. 7b).

The pre-cleavage folds have centimetre to metre sizes and interlimb angles ranging from close to gentle. Both strongly asymmetric and more or less symmetric folds occur. The former all show a roughly south-verging asymmetry, ranging from SWverging to SE-verging. Some pre-cleavage folds have fold shapes comparable with those of the syn-cleavage folds. Others, however, have different fold geometries, resembling types 1C, 1D, 2F, 3C and 3D of Hudleston (1973).

The pre-cleavage folds exhibit a significant spread in orientation (Fig. 8). The plunge ranges from subhorizontal to steeply plunging and a difference of almost $90^{\circ}$ exists between the two most extreme plunge directions. Some axial surfaces are markedly oblique to the main cleavage trend $\left(101-281^{\circ}\right)$, whereas others are more or less parallel to the main cleavage trend.

Apart from the pre-cleavage nature, and the stronger geometric variation with respect to the syn-cleavage folds, another char2 acteristic feature of the pre-cleavage folds is their common, 


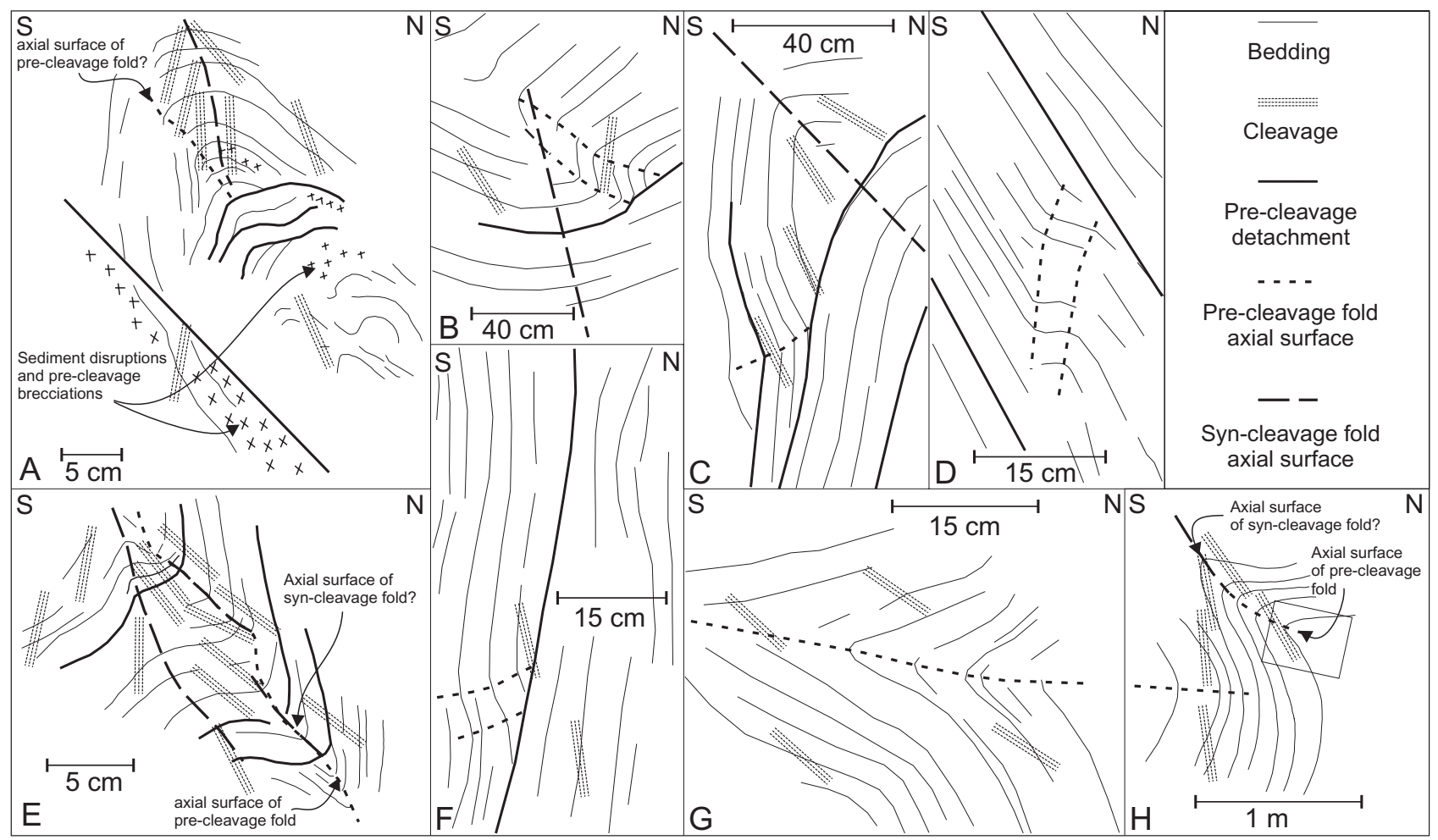

Fig. 7. Pre-cleavage deformation structures in the Abbaye de Villers Formation and their relationship with syn-cleavage deformation structures. (a) Precleavage deformation structures (folds, detachments and related soft-sediment deformation), affected by a syn-cleavage antiform, with a well-developed divergent cleavage fan (outcrop 12, lower part). (b) Pre-cleavage fold pair and related pre-cleavage detachment, affected by a syn-cleavage synform (outcrop 4, lower, northern part). Cleavage shows a divergent fan, symmetrical about the syn-cleavage synform axial surface, but crosscuts the axial surface of the pre-cleavage fold pair. (c) Stepfold-like syn-cleavage antiform, with small pre-cleavage fold in its steep limb and related pre-cleavage detachments (outcrop 6, southern part; see Fig. 5). The cleavage shows a well-developed divergent fan in the syn-cleavage fold, but crosscuts the precleavage fold. (d) Isolated fold pair, separated from overlying and underlying unfolded beds by pre-cleavage detachments (outcrop 12, central, lower part). (e) Syn-cleavage folds superimposed on pre-cleavage folds and deforming pre-cleavage detachments (outcrop 12, central, lower part). (f) Pre-cleavage fold pair and related detachment above unfolded beds (outcrop 3, northern, lower part). (g, h) Relationship between cleavage and pre-cleavage folds. Cleavage is only slightly oblique to the axial surface of the pre-cleavage antiform, but is almost perpendicular to the axial surface of a gentle pre-cleavage synform associated with this antiform. Towards higher levels, the cleavage-fold relationships seemingly suggest a syn-cleavage origin (outcrop 12 , lower, northern part).

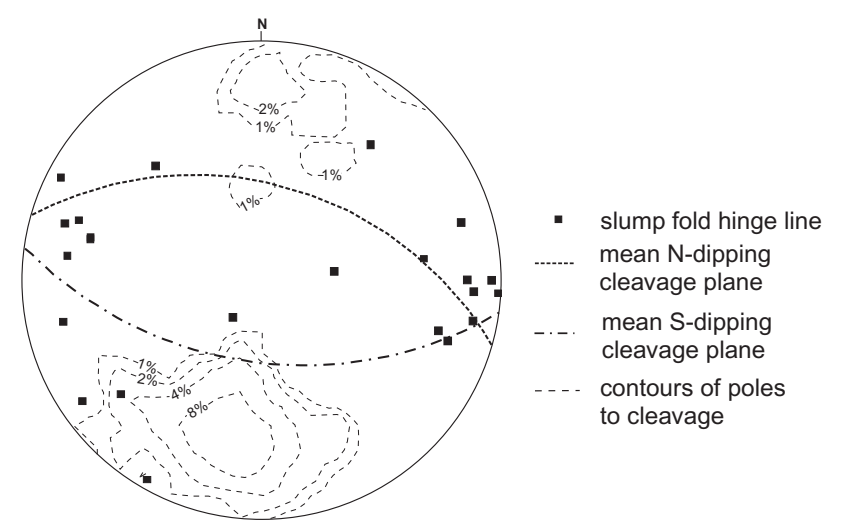

Fig. 8. Lower-hemisphere equal-area projection showing the orientation of the pre-cleavage fold hinge lines and the cleavage (mean cleavage planes and contours of poles to cleavage). isolated, intraformational position between 'non-folded' beds (i.e. not folded by pre-cleavage folds) and their close association with pre-cleavage detachments (Fig. 7d and f). The term 'detachment' is used here for any pre-cleavage truncational surface with a low bedding cut-off angle, irrespective of whether or not there is actual evidence of slip. Hence it includes surfaces of erosional truncation. The pre-cleavage detachments are often welded, and often result in a stacking of sequences, leading to strong local thickness changes (Figs 5, 7a, c, e, and 9). In some cases, the detachments truncate the pre-cleavage folds (Figs 7e and 9a), whereas in other cases they are folded by the pre-cleavage folds (Fig. 9a). However, in all cases, the detachments are folded by the syn-cleavage folds, thus implying a pre-cleavage origin. Ideally, the pre-cleavage nature of the detachments and, where present, their associated breccias, is demonstrated by the cross16 cutting relationship of the cleavage. Often, however, their pre7 cleavage nature is reflected by less obvious features such as the 8 association with zones of pre-cleavage, internal deformation of 


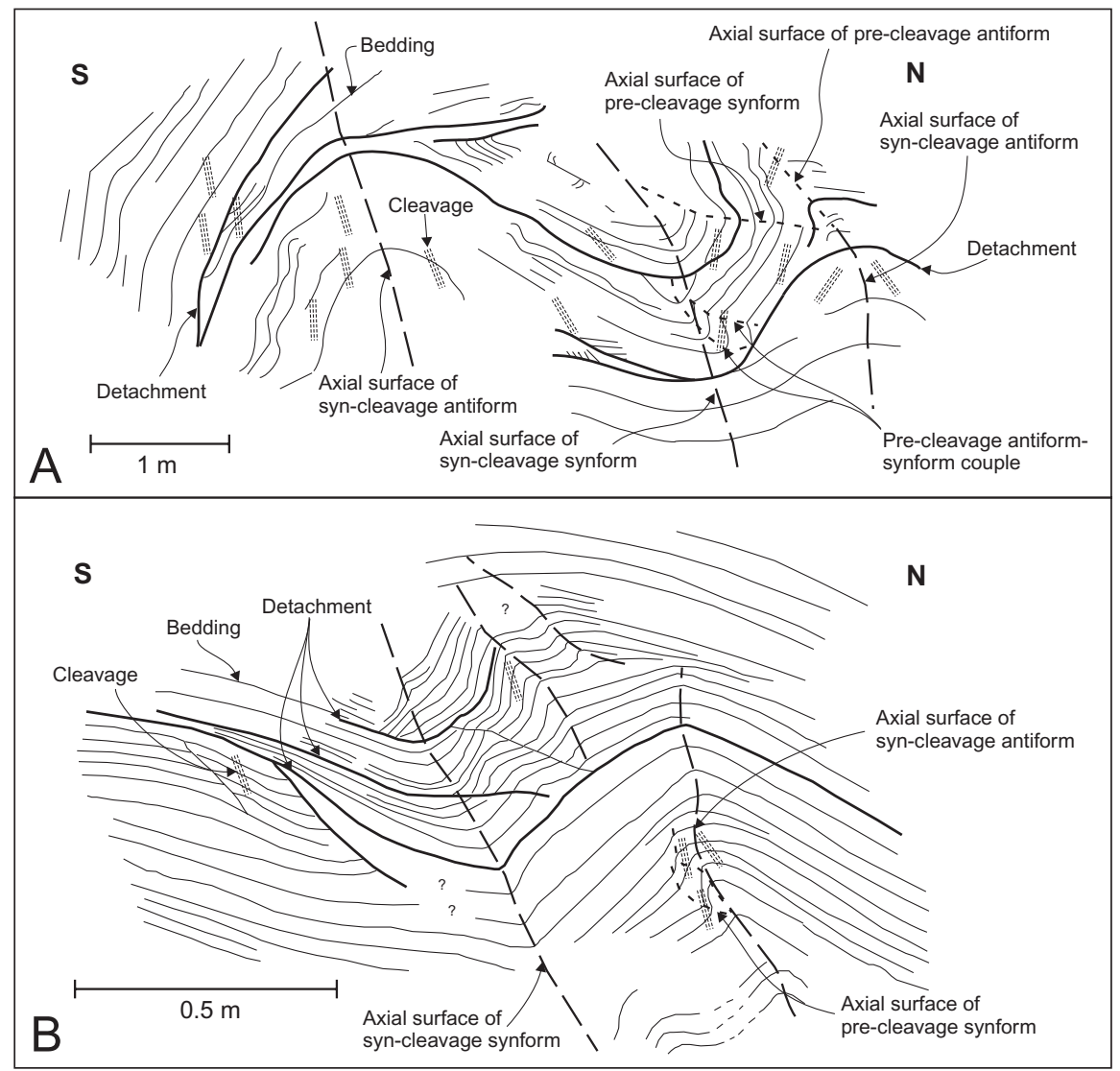

Fig. 9. Examples of the spatial relationship between syn-cleavage folds and precleavage deformation structures: (a) outcrop 4; (b) outcrop 11. The syn-cleavage folds occur superimposed on pre-existing precleavage folds, often amplifying these, and on zones of abrupt thickness changes related to pre-cleavage detachments. the sediments (e.g. zones in which the sand layers are disrupted into small sand lenses within a clay matrix or zones with abrupt terminations of individual layers).

\section{Geological significance of the pre- and syn-cleavage folds}

The metre-scale syn-cleavage folds, as well as the hectometrescale gentle host antiform, are all of tectonic origin and are attributed to the Brabantian deformation phase (see Debacker 2001; Verniers et al. 2002; Debacker et al. 2005). Taking into account the asymmetry (S-shaped) of the metre-scale syncleavage folds and their position within the subhorizontal limb of the syn-cleavage host antiform (Fig. 3), they probably represent parasitic folds related to this antiform. In this respect, and taking into account a south-dipping cleavage in the southern antiform limb, one would expect comparable folds, with an opposing asymmetry (Z-shaped) in the southern antiform limb (southern part of Fig. 3). However, such folds have not been observed.

The pre-cleavage folds either formed during an older tectonic deformation phase or are a result of slumping (see Debacker et al. 2001). In the study area, as well as in the other outcrop areas of the Brabant Massif, there is no evidence for more than one tectonic deformation phase (e.g. Sintubin 1999; Debacker 2001; Verniers et al. 2002; Debacker et al. 2005, and references therein). In contrast, the pre-cleavage folds have characteristics commonly attributed to slump folds. These are the isolated intraformational position between non-folded beds (e.g. Fig. 7d), the truncation of folds by overlying, younger beds (Figs 7e and 9a), the dispersed orientation of the fold axes (Fig. 8), the often irregular fold shape (Fig. 9), the association with other softsediment deformation features such as welded detachments, welded faults and disrupted sediments, the absence of fold- or detachment-related veins or cleavage and the parallel or southward downcutting nature of the detachments with respect to underlying beds (see Jones 1939; Kuenen 1949; Helwig 1970; Corbett 1973; Rupke 1976; Woodcock 1976; Elliott \& Williams 1988). For these reasons, the pre-cleavage folds are interpreted as slump folds. By means of the mean axis method (Jones 1939) and the separation arc method (Hansen 1965), the asymmetry of the slump folds was used to deduce the sense and direction of slumping and the probable strike of the corresponding palaeoslope (see Woodcock 1979). Both methods give similar results and suggest slumping from north (NNW) to south (SSE), and hence a probably south-dipping, east-west-trending palaeoslope (Beckers 2003, 2004).

\section{Relative position of the pre- and syn-cleavage folds}

The syn-cleavage folds and the pre-cleavage folds show a close spatial relationship. Not only do pre-cleavage folds often occur in the hinge zones of the syn-cleavage folds (e.g. Fig. 7b, c, e), but, more importantly, of the observed metre-scale syn-cleavage fold pairs (synform-antiform couple), at least one fold always coincides with smaller pre-cleavage folds and thickness changes related to pre-cleavage detachments (Figs 7a-c, e, and 9a, b). In Figure 5 (see Fig. 7c), for instance, the axial surface of the syncleavage antiform runs along the hinges of several pre-cleavage antiforms, probably formed by movement along, and stacked on top of one other by, pre-cleavage detachments. Similarly, in 
Figure 7a, the syn-cleavage antiform occurs superimposed on a zone of strong pre-cleavage deformation. In addition, it appears that the syn-cleavage antiforms tend to coincide with precleavage antiforms and zones with an abrupt thickness increase as a result of stacking along detachments, whereas syn-cleavage synforms tend to coincide with pre-cleavage synforms and zones of abrupt thickness decrease. The syn-cleavage antiforms in Figure 5 (see Fig. 7c), Figure 7a, h, and in the northern part of Figure 9a all occur superimposed on pre-cleavage antiforms or on zones characterized by a significant local thickening as a result of pre-cleavage deformation. Similarly, the syn-cleavage synforms in Figure 7e, Figure 9a (see Fig. 7b) and Figure 9b occur superimposed on a pre-cleavage synform or on zones characterized by a significant local thinning caused by precleavage deformation.

Also on a large scale, an apparent spatial relationship exists between the pre-cleavage and syn-cleavage metre-scale folds. Both occur within the same part of the studied outcrop section. Because they result from slumping, the pre-cleavage folds should be restricted to particular stratigraphic levels, in this case the older unit of the Abbaye de Villers Formation (Fig. 3). However, the syn-cleavage folds, being of tectonic origin, seem also to be related to this level. Considering the common scarcity of mesoscale tectonic folds in the limbs of the large-scale host folds in the Ordovician and Silurian sequences of the Brabant Massif (Debacker et al. 1999, 2001, 2005; Debacker 2001), and the paucity of meso-scale folds in the Ordovician sequences of the Thyle valley, representing the subhorizontal limb of a kilometrescale stepfold (Herbosch et al. 2002), it is surprising to find such a high local concentration of metre-scale tectonic folds along the northern part of the studied section. In addition, as pointed out above, although these folds probably represent parasitic folds related to the hectometre-scale host antiform, they are observed only within its subhorizontal limb (Fig. 3). In this respect, outcrop 13 deserves special attention. This is the only outcrop with pre-cleavage folds observed in the southern limb of the hectometre-scale antiform (Fig. 3). In this outcrop, decimetre- to metre-scale south-verging pre-cleavage folds occur within a $2 \mathrm{~m}$ wide zone between undeformed, gently south-dipping beds. No syn-cleavage folds occur within this outcrop.

\section{Comparison with the Abbaye de Villers Formation in the Sennette valley at Virginal}

In the railway section at Virginal, in the Sennette valley, c. $20 \mathrm{~km}$ to the west of the Thyle valley (Fig. 1), the lower part of the Abbaye de Villers Formation occurs in a subvertical to steeply SW-dipping, SW-younging limb of a hectometre-scale fold. Along this outcrop section, the upper parts of the Abbaye de Villers Formation and the entire Tribotte Formation are removed by faulting (Fig. 10; compare Debacker et al. 2004a, fig. 9).

Within this lower part of the Abbaye de Villers Formation, a $c$. $330 \mathrm{~m}$ thick zone occurs with metre-scale pre-cleavage folds 4 and related pre-cleavage deformation structures (detachments, 5 brecciations), which, using the same argument as above, have 6 been attributed to slumping (Debacker 2001; Debacker et al. 7 2003). Although having an identical lithostratigraphic position to 8 the level studied in the Thyle valley, it cannot be ascertained 9 whether both levels have an identical age. Characteristically, 20 bedding in this zone of pre-cleavage deformation is oriented c. $020^{\circ}$ clockwise with respect to the regional trend (Fig. 10).

2 Because of the steep bedding dip, and the oblique orientation 3 with respect to the regional trend, the inferred slump direction 4 varies significantly with the chosen values of the regional fold 5 axis and mean bedding orientation. A northern, northeastern or ${ }_{6}$ eastern slump source is inferred (Debacker, unpubl. data), being 7 compatible with the northern slump source inferred in the Thyle 8 valley (see Beckers 2003, 2004).

Significantly, within this steep limb there are no syn-cleavage 30 folds that show a spatial relationship with individual pre-cleavage deformation structures. The only observed syn-cleavage fold pair, 2 a metre- to decametre-scale open, rounded antiform-synform s couple, occurs at the southern, upper limit of the pre-cleavage 34 deformation zone (Fig. 10) and cannot be linked to individual 35 pre-cleavage deformation structures. Hence, this section mark${ }_{36}$ edly contrasts with the section studied in the Thyle valley. First,

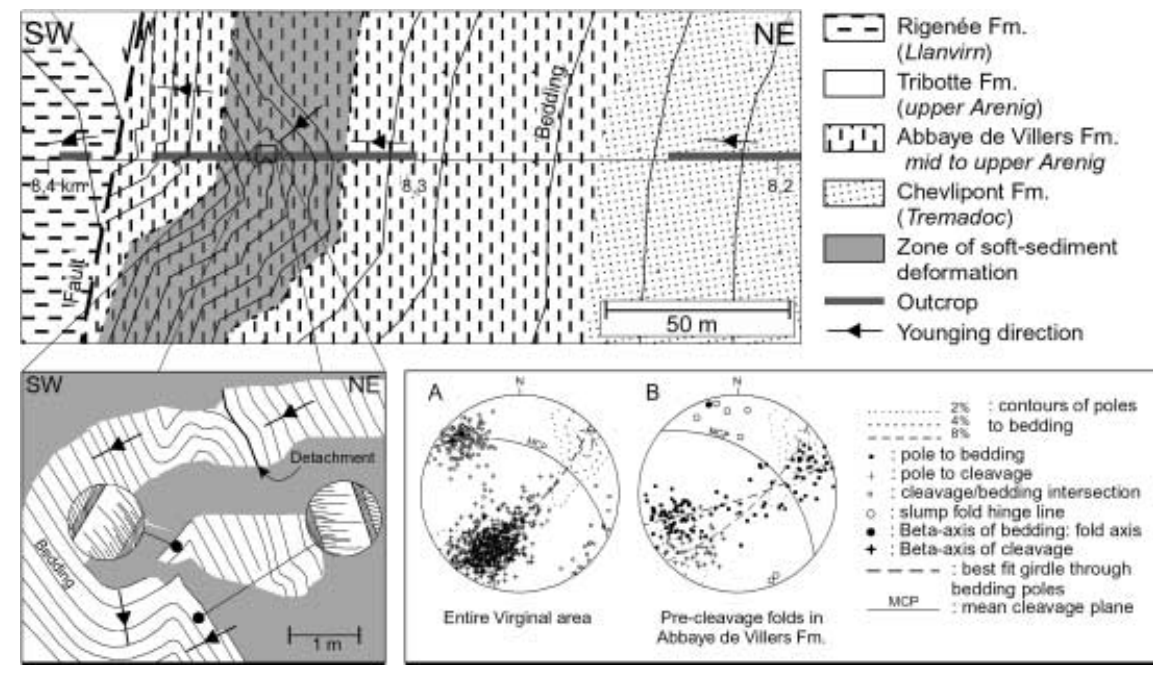

Fig. 10. The soft-sediment deformation level in the lower part of the Abbaye de Villers Formation in the railway section at Virginal, Sennette valley (see Fig. 1 for location; after Debacker et al. 2003, 2004a). The lower left inset shows the cleavage-bedding relationships within a pre-cleavage fold pair (after Debacker et al. 2003). The lower right frame shows lowerhemisphere equal-area projections: projection A shows bedding, cleavage and cleavage-bedding intersections associated with syn-cleavage folds from the entire Virginal area; projection B shows bedding and fold hinge lines of pre-cleavage folds as well as cleavage within the soft-sediment deformation zone in the Abbaye de Villers Formation. For comparison, bedding pole contours of projection $\mathrm{A}$ are added as a grey background in projection $\mathrm{B}$. The different orientation of the pre-cleavage folds (projection B) with respect to the (syn-cleavage) regional trend (projection A) should be noted. 
it complies with the general situation of the Ordovician and Silurian sequences of the Brabant Massif, in which the limbs of large-scale fold structures are virtually free of parasitic fold structures. Second, it does not show a clear spatial relationship between individual pre-cleavage deformation structures and syncleavage folds.

\section{Discussion}

One of the most cited characteristics of slump folds is the dispersed fold-axis orientation, even from within single slump sheets (Helwig 1970; Lajoie 1972; Woodcock 1976, 1979). In the soft-sediment deformation level in the Thyle valley, however, the tectonic fold orientations also exhibit a considerable spread. Taking into account observations in other Ordovician and Silurian outcrop areas of the Brabant Massif (e.g. Fig. 10), it appears that the spread in tectonic fold hinge-line orientations in this part of the Abbaye de Villers Formation is remarkably high (see Debacker et al. 1999, 2004a, b; Debacker 2001). It is likely that this is related to the variable orientations of the slump folds.

The spatial relationship between the two fold types and the apparent influence of the slump fold orientations on the tectonic folds suggest that it is the presence of slump folds that controls the occurrence of the metre-scale tectonic folds. Also, the apparent stratigraphically restricted occurrence of the metre-scale tectonic folds in the subhorizontal limb of the hectometre-scale gentle host antiform in the Thyle valley (Fig. 3; outcrops 1-12 and 14) may be related to the presence of the soft-sediment deformation structures. Alternatively, one might also consider lithological differences between the lower unit and the upper unit of the Abbaye de Villers Formation as an explanation for the apparent stratigraphically restricted occurrence. However, the differences between these units are not sufficient to explain the total absence of parasitic folds in the upper unit compared with the abundance of metre-scale parasitic folds in the lower unit (Fig. 4). In addition, this cannot explain the apparent absence of metre-scale tectonic folds in the lower unit in the southern, south-dipping antiform limb (outcrop 13).

As pointed out above, in outcrop 13 in the Thyle valley (Fig. 3 ), and in the railway section at Virginal in the Sennette valley (Fig. 10), there are no tectonic folds that can be linked to individual slump features. Possibly, this is a result of the relative asymmetry of the tectonic folds and the slump folds. As shown by experiments and numerical models, the influence of a perturbation on folding and on final fold geometry depends not only on strain, strain rate and material properties, but also on the spacing, size and asymmetry of the perturbations (Lewis \& Williams 1978; Abbassi \& Mancktelow 1990; Mancktelow 1999; Zhang et al. 2000; Williams \& Jiang 2001; Jeng et al. 2002). Because of the northern slump source, the slump folds have a similar asymmetry to the metre-scale tectonic folds in the northern, subhorizontal limb of the hectometre-scale, tectonic antiform (Fig. 11a; compare Fig. 3). In this limb the tectonic fold axial surfaces will at least partly coincide with the axial surfaces of the pre-cleavage folds at which they originate (e.g. Figs 5 and 7c, e, h, and the northern parts of Fig. 9a and b). In the southdipping, southern antiform limb, however, the slump fold asymmetry will oppose that of the expected metre-scale tectonic folds (outcrop 13 in Thyle valley and Virginal railway section in Sennette valley). Hence, we suggest that, within the Abbaye de Villers Formation, the parasitic tectonic folds develop on slump folds only in those cases where the slump fold asymmetry matches the asymmetry of the parasitic tectonic folds.

Whether or not a specific slump fold or slump-related 1 irregularity will give rise to a tectonic fold depends also on the distance between the adjacent slump folds, relative to the dominant wavelength of the tectonic folds (Abbassi \& Mancktelow 1990; Mancktelow 1999; Williams \& Jiang 2001). In Figure $11 \mathrm{~b}$, if the half-wavelengths of the tectonic folds were similar to the spacing between the synform and antiform of each slump fold pair, a tectonic fold would be expected in the four positions marked (two synforms and two antiforms). However, often only one fold of each slump fold pair develops into a tectonic fold. In Figure 5 and the northern part of Figure $9 \mathrm{a}$ and $\mathrm{b}$, a tectonic antiform forms along the antiform of the slump fold pair, whereas the adjacent synformal slump fold is not used. Similarly, the tectonic synform in Figure 9a develops predominantly along the synform of the slump fold pair, seemingly without any influence of the adjacent antiformal slump fold. In addition, once a tectonic antiform (synform) initiates on a pre-existing slump fold or related structure, which forms a suitable perturbation, an adjacent tectonic synform (antiform) will also develop, the position of which may be influenced more by the dominant fold wavelength and by the development of the adjacent antiform (synform) than by the presence of a perturbation. Possibly, this is what happens in Figure 9b. Unlike the adjacent tectonic synform, which has a very distinct hinge zone centred on a significant precleavage deformation zone, the tectonic antiform apparently

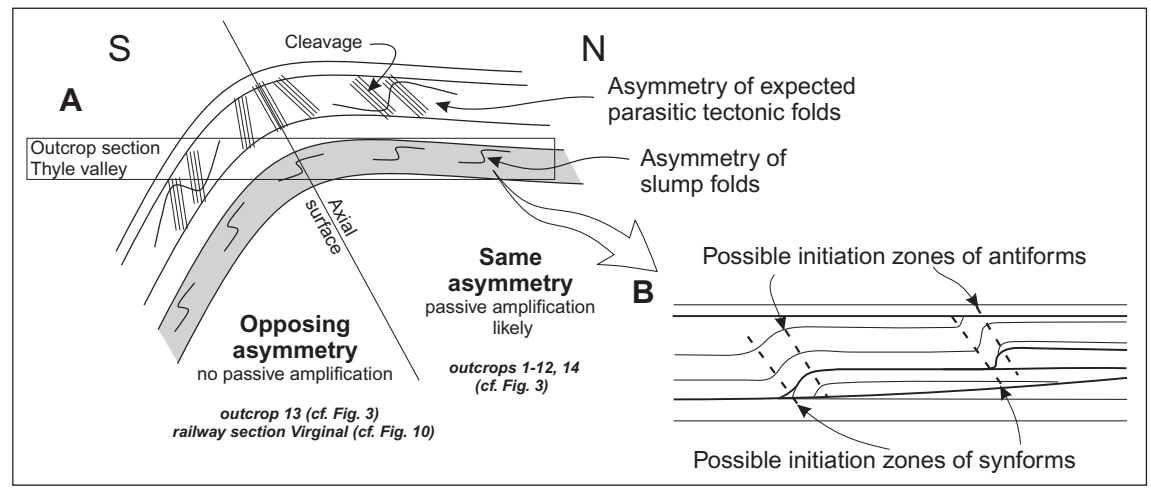

Fig. 11. Conceptual representation of (a) the asymmetry of the slump folds and the expected tectonic folds throughout a hectometre-scale south-verging antiform in the Abbaye de Villers Formation (see Figs 3 and 10) and (b) the slump-related deformation geometry in the subhorizontal, hectometre-scale fold limb in the Thyle valley, with indication of the possible initiation zones for tectonic folds. In the southern antiform limb, passive amplification of slump folds during tectonic shortening is unlikely, because of the high angle between the slump fold axial surfaces, on the one hand, and the cleavage and the expected tectonic fold axial surfaces, on the other hand. (See text for discussion.) 
developed on a pre-cleavage fold of very limited extent and, although the tectonic antiform shape seems to continue towards higher levels, its axial surface is irregular and very difficult to trace. Possibly, this antiform formed primarily as a result of the adjacent synform. The above observations indicate that the dominant wavelength of the tectonic folds is larger than that of many of the slump folds, and suggest that, besides perturbation asymmetry, size and spacing, the material properties also play a significant role.

Finally, the question can be raised of whether the tectonic folds entirely result from active folding after initiation on slumprelated perturbations, or whether a significant amount of passive amplification of pre-existing slump folds was involved. On the one hand, during layer-parallel tectonic shortening and cleavage development, a further, passive tightening and amplification can be expected for slump folds of which the axial surface is subparallel to the cleavage (e.g. synform in Fig. 7e). Considering the similar asymmetry of the slump folds and the tectonic folds in the subhorizontal hectometre-scale antiform limb in the Thyle valley, and the observation that tectonic antiforms (synforms) tend to develop on antiformal (synformal) slump folds, passive amplification is likely to have occurred. On the other hand, however, the marked divergent cleavage fanning implies active folding. Also, the size difference between the tectonic folds and many of the slump folds suggests that active folding took place. Hence, it is likely that both phenomena occurred, their relative importance varying from fold to fold. Interestingly, although, regardless of their asymmetry, the slump folds in the southern, south-dipping antiform limb do represent an irregularity of comparable size to the other slump folds and hence are potential perturbations during tectonic shortening, no tectonic folds are observed that can be linked to individual soft-sediment deformation structures. Because of their asymmetry, opposing that of the expected tectonic folds, passive amplification of these slump folds cannot occur. Possibly, the absence of tectonic folds at this locality is a direct result of the absence of passive amplification. Conversely, it may be possible that within the Abbaye de Villers Formation, because of the strain, strain rate and material properties, the process of tectonic fold development on pre-existing slump folds initiates by means of passive amplification, and only later changes into active folding.

\section{Conclusions}

3 In the southern Brabant Massif, both pre-cleavage and metrescale syn-cleavage folds occur within a particular stratigraphic level of the Lower Ordovician Abbaye de Villers Formation. The pre-cleavage folds and related structures are attributed to slumping from a northern source, whereas the syn-cleavage folds formed during the Brabantian deformation phase (late Llandovery-Emsian).

Both the position and, to a certain extent, the geometry of the metre-scale tectonic folds appear to be controlled by the slump folds. Hence, the slump folds are considered as perturbations at which the tectonic folds initiated. However, not all soft-sediment deformation structures give rise to tectonic folds. In those cases where the slump folds have an asymmetry opposing that of the expected tectonic folds, there are no tectonic folds that can be linked to individual soft-sediment deformation structures. In addition, even though having a similar asymmetry to the expected tectonic folds, not every fold of an antiform-synform slump fold pair gives rise to a tectonic fold and apparently the tectonic fold forms on the more 'suitable' soft-sediment deformation structure. Some observations also suggest that, once a tectonic fold forms on a suitable slump structure, an adjacent fold develops, the position of which may or may not be controlled by pre-existing slump structures. Probably, the latter depends on whether or not the pre-existing perturbation is more important than the material properties controlling the dominant 6 wavelength of the tectonic folds. The fact that the dominant wavelength of the tectonic folds is larger than that of the slump folds suggests that, although initially the perturbations (slump features) appear to control the initiation of the tectonic folds, during tectonic fold amplification the material properties become more important. This is in agreement with the results of 2 experiments and numerical models, which indicate that the 3 influence of a perturbation on folding and on final fold geometry 4 depends not only on strain, strain rate and material properties, but also on the perturbation spacing, size and asymmetry (Lewis \& Williams 1978; Abbassi \& Mancktelow 1990; Mancktelow 1999; Zhang et al. 2000; Williams \& Jiang 2001; Jeng et al. 2002).

Although in the specific case of the relationship between perturbation and buckle folding, experiments and numerical 21 models may adequately describe and predict the development of 2 buckle folds at particular localities, there are, judging from the 3 geological literature, very few documented natural examples of 24 this. Taking into account the common occurrence of slump folds 5 and related features, the rather irregular $3 \mathrm{D}$ nature of sedimentary sequences and the abundance of lenticular sedimentary (e.g. 7 channels) or volcanic bodies (e.g. rhyolitic lava flows), many 28 more cases are expected in which individual natural buckle folds 29 may be linked to specific perturbations. Probably, this discreo pancy is a result of the complexity of geological materials, as 1 compared with the materials used in numerical and experimental 2 studies. This complexity of natural layer systems, in which a large number of possible perturbations coexist, makes it difficult ${ }^{4}$ to link a specific natural buckle fold to a specific irregularity. In addition, because of the degree of exposure and relative scale of 5 the folds, the natural perturbation usually remains unknown.

40 We wish to acknowledge I. Kenis and M. van Noorden for helpful 1 discussions. We are most grateful to N. Woodcock, T. Needham and 2 I. Alsop for constructive remarks on the original manuscript. T. Debacker 3 is a Postdoctoral Fellow of the Fund for Scientific Research-Flanders 4 (F.W.O.-Vlaanderen). This work forms part of research projects 5 G.0094.01 and G.0271.05 of the F.W.O.-Vlaanderen.

\section{${ }_{46}$ References}

47 Abbassi, M.R. \& Mancktelow, N.S. 1990. The effect of initial perturbation shape 48 and symmetry on fold development. Journal of Structural Geology, 12, 49 273-282.

50 Abbassi, M.R. \& Mancktelow, N.S. 1992. Single layer buckle folding in non51 linear materials-I. Experimental study of fold development from an isolated 52 initial perturbation. Journal of Structural Geology, 14, 85-104.

53 Anthoine, R. \& Anthoine, P. 1943. Les assises de Mousty et de Villers-la-Ville 54 du bassin supérieur de la Dyle. Annales de la Société Géologique de 55 Belgique, 66, M53-M170.

56 BeCKers, R. 2003. Vergelijking van de plooien in de Abbaye de Villers en 57 Chevlipont formaties (Ordovicium) in de omgeving van de Abdij van Villers, 58 Thyle-vallei, Massief van Brabant. MSc thesis, Universiteit Gent.

59 BeCKers, R. 2004. Comparison of folds in the Chevlipont and Abbaye de Villers

60 Formations, near the abbey of Villers, Thyle valley, Brabant Massif. 61 Geologica Belgica, 7, 357-359.

62 Coвbold, P.R. 1975. Fold propagation in single embedded layers. Tectonophysics, 63 27, 333-351.

64 Corbett, K.D. 1973. Open-cast slump sheets and their relationship to sandstone 65 beds in an Upper Cambrian flysch sequence, Tasmania. Journal of Sedimen66 tary Petrology, 43, 147-159.

67 Debacker, T. N. 2001. Palaeozoic deformation of the Brabant Massif within 68 eastern Avalonia: how, when and why? $\mathrm{PhD}$ thesis, Universiteit Gent. 
Debacker, T.N., Sintubin, M. \& Verniers, J. 1999. Cleavage/fold relationships 2 in the Silurian metapelites, southeastern Anglo-Brabant fold belt (Ronquières, 3 Belgium). Geologie en Mijnbouw, 78, 47-56.

4 Debacker, T.N., Sintubin, M. \& Verniers, J. 2001. Large-scale slumping 5 deduced from structural and sedimentary features in the Lower Palaeozoic 6 Anglo-Brabant fold belt, Belgium. Journal of the Geological Society, London, 7 158, 341-352.

8 Debacker, T.N., Herbosch, A., Sintubin, M. \& Verniers, J. 2003. Palaeozoic 9 deformation history of the Asquempont-Virginal area (Brabant Massif, 10 Belgium): large-scale slumping, low-angle extensional detachment develop1 ment (the Asquempont fault redefined) and normal faulting (the Nieuwpoort12 Asquempont fault zone). Memoirs of the Geological Survey of Belgium, 49, 13 1-30.

14 Debacker, T.N., Herbosch, A., Verniers, J. \& Sintubin, M. 2004a. Faults in the 15 Asquempont area, southern Brabant Massif, Belgium. Netherlands Journal of 16 Geosciences, 83, 49-65.

17 Debacker, T.N., Sintubin, M. \& Verniers, J. 2004b. Transitional geometries 18 between gently plunging and steeply plunging folds: an example from the 19 Lower Palaeozoic Brabant Massif, Anglo-Brabant deformation belt, Belgium. 20 Journal of the Geological Society, London, 161, 641-652.

21 Debacker, T.N., Dewaele, S., Sintubin, M., Verniers, J., Muchez, Ph. \& 22 Boven, A. 2005. Timing and duration of the progressive deformation of the 23 Brabant Massif, Belgium. Geologica Belgica, $\mathbf{x x}, \mathbf{x x}-\mathbf{x x x}$

24 De Vos, W., Verniers, J., Herbosch, A. \& Vanguestaine, M. 1993. A new 25 geological map of the Brabant Massif, Belgium. Geological Magazine, 130, $26 \quad 605-611$.

27 Elliott, C.G. \& Williams, P.F. 1988. Sediment slump structures: a review of 28 diagnostic criteria and application to an example from Newfoundland. 29 Journal of Structural Geology, 10, 171-182.

Fleuty, M.J. 1964. The description of folds. Proceedings of the Geologists' 31 Association, 75, 461-492.

32 Hansen, E. 1965. Methods of deducing slip-line orientations from the geometry of 33 folds. Carnegie Institution of Washington, Yearbook, 65, 387-405.

34 Helwig, J. 1970. Slump folds and early structures, Newfoundland Appalachians. 35 Journal of Geology, 78, 172-187.

36 Herbosch, A. \& Lemonne, E. 2000. Carte Nivelles-Genappe no. 39/7-8, Carte 37 géologique de Wallonie, échelle 1/25000. Ministère de la Région Wallonne, 38 Namur.

39 Herbosch, A., Verniers, J., Debacker, T.N., Billiaert, B., De Schepper, S. \& 40 Belmans, M. 2002. The Lower Palaeozoic stratigraphy and sedimentology of 41 the Brabant Massif in the Dyle and Orneau valleys and of the Condroz Inlier 42 at Fosses: an excursion guidebook. Geologica Belgica, 5, 71-143.

43 Hudleston, P.J. 1973. Fold morphology and some geometrical implications of 44 theories of fold development. Tectonophysics, 16, 1-46.

45 Jeng, F.S., Lin, M.L., LAI, Y.C. \& Teng, M.H. 2002. Influence of strain rate on 46 buckle folding of an elasto-viscous single-layer. Journal of Structural 47 Geology, 24, 501-516.

48 Johnson, T.E. 1991. Nomenclature and geometric classification of cleavage49 transected folds. Journal of Structural Geology, 13, 261-274.

50 Jones, O.T. 1939. The geology of the Colwyn Bay District: a study of submarine slumping during the Salopian Period. Quarterly Journal of the Geological 2 Society, London, 95, 335-382.

3 Kuenen, P.H. 1949. Slumping in the Carboniferous rocks of Pembrokeshire. 4 Quarterly Journal of the Geological Society, London, 104, 365-385.

5 LAJoie, J. 1972. Slump fold axis orientations: an indication of paleoslope? Journal 6 of Sedimentary Petrology, 42, 584-586.

7 Legrand, R. 1968. Le Massif du Brabant. Mémoires pour Servir à l'Explication 8 des Cartes Géologiques et Minières de la Belgique, 9, 1-148.

9 LeWis, R.W. \& Williams, J.R. 1978. A finite-element study of fold propagation in 10 a viscous layer. Tectonophysics, 44, 263-283.

11 Mancktelow, N.S. 1999. Finite-element modelling of single-layer folding in 12 elasto-viscous materials: the effect of initial perturbation geometry. Journal 13 of Structural Geology, 21, 161-177.

14 Мiснот, P. 1977. L'Ordovicien de la vallée de la Thyle (Brabant): structure 15 tectonique, stratigraphie et lithologie. Annales de la Société Géologique de 16 Belgique, 100, 223-231.

17 Price, N.J. \& Cosgrove, J.W. 1990. Analysis of Geological Structures. Cambridge 18 University Press, Cambridge.

19 Rupke, N.A. 1976. Large-scale slumping in a flysch basin, Southwestern Pyrenees. 20 Journal of the Geological Society, London, 132, 121-130.

21 Sintubin, M. 1997. Cleavage-fold relationships in the Lower Paleozoic Brabant 22 Massif (Belgium). Aardkundige Mededelingen, 8, 161-164.

23 Sintubin, M. 1999. Arcuate fold and cleavage patterns in the southeastern part of 24 the Anglo-Brabant Fold Belt (Belgium): tectonic implications. Tectonophy25 sics, 309, 81-97.

26 Van Grootel, G., Verniers, J., Geerkens, B., Laduron, D., Verhaeren, M., 27 Hertogen, J. \& De Vos, W. 1997. Timing of magmatism, foreland basin 28 development, metamorphism and inversion in the Anglo-Brabant fold belt. 29 Geological Magazine, 134, 607-616.

30 Verniers, J., Herbosch, A. \& Vanguestaine, M. et al. 2001. Cambrian31 Ordovician-Silurian lithostratigraphical units (Belgium). Geologica Belgica, 32 4, 5-38.

33 Verniers, J., Pharaoh, T. \& André, L. et al. 2002. The Cambrian to mid 34 Devonian basin development. In: Winchester, J.A., PharaOH, T.C. \& 35 Verniers, J.et al. (eds) Palaeozoic Amalgamation of Central Europe. 36 Geological Society, London, Special Publications, 201, 47-93.

37 Williams, P.F. \& Jiang, D. 2001. The role of initial perturbations in the 38 development of folds in a rock-analogue. Journal of Structural Geology, 23, 39 845-856.

40 Williams, J.R., Lewis, R.W. \& ZienkiewicZ, O.C. 1978. A finite-element analysis 41 of the role of initial perturbations in the folding of a single viscous layer. 42 Tectonophysics, 45, 187-200.

43 Woodcock, N.H. 1976. Structural style in slump sheets: Ludlow Series, Powys, 44 Wales. Journal of the Geological Society, London, 132, 399-415.

45 Woodcock, N.H. 1979. The use of slump structures as palaeoslope orientation 46 estimators. Sedimentology, 26, 83-99.

47 Zhang, Y., Mancktelow, N.S., Hobbs, B.E., Ord, A. \& Mühlhaus, H.B. 2000. 48 Numerical modelling of single-layer folding: clarification of an issue 49 regarding the possible effect of computer codes and the influence of initial 50 irregularities. Journal of Structural Geology, 22, 1511-1522. 